\title{
Screening of Anxiolytic and Antidepressant of Methanolic Leaves Extract of Syzygium Cumini in Mice
}

\author{
Ahad Abdul Rehman ${ }^{1}$, Azra Riaz ${ }^{2}$, Muhammad Arif Asghar ${ }^{3, *}$, Bushra Sikander ${ }^{2}$, Moona Baig $^{4}$ \\ ${ }^{1}$ Department of Pharmacology, Faculty of Pharmacy, Jinnah Sindh Medical University, Karachi, Pakistan \\ ${ }^{2}$ Department of Pharmacology, Faculty of Pharmacy and Pharmaceutical Sciences, University of Karachi, Pakistan \\ ${ }^{3}$ Department of Pharmaceutics, Faculty of Pharmacy, Jinnah Sindh Medical University, Karachi, Pakistan \\ ${ }^{4}$ Department of Pathology, Dow International Medical College, Dow University of Health Sciences, Karachi, Pakistan
}

Authors' Contributions

1, 2 Conception \& study design

1, 5 Data Collection \& Processing

1, 3, 4 Data Analysis and/or interpretation

1, 2, 3, 4, 5 Drafting of Manuscript

2, 3 Critical Review

\section{Acknowledgement}

Authors are acknowledging to the Department of Pharmacology, University of Karachi for giving us a financial and technical support to conduct this study.

\section{Article info.}

Received: February 19, 2020

Accepted: September 12, 2020

Funding Source: Nil

Conflict of Interest: Nil

Cite this article: Rehman AA, Riaz A, Asghar

MA, Sikander B, Baig M. Screening of Anxiolytic and Antidepressant of Methanolic Leaves Extract of Syzugium Cumini in Mice, RADS J Pharm Pharm Sci. 2020; 8(2):91-97.

*Address of Correspondence Author: m.arifasgher@hotmail.com

\begin{abstract}
Background: Anxiety and depression are very common in clinical practice and reduce the overall quality of life. In recent years, various researchers have focused on natural products which are derived from medicinal plants. Studies suggested that diet rich in flavonoids, vitamins and antioxidants are the important components in reduction of anxiety and depression.
\end{abstract}

Objective: Hence current investigation was aimed to assess the anxiolytic and antidepressant effects of Syzygium cumini in mice at 125, 250 and 500 $\mathrm{mg} / \mathrm{kg}$.

Methods: These effects were mainly evaluated twice at $8^{\text {th }}$ and $15^{\text {th }}$ days by elevated plus maze, open field test, forced swimming test and tail suspension test.

Results and Conclusion: In open field test S. cumini showed escalation rearing in numbers and its duration which indicates improved exploratory behavior and locomotor activity of the animals. In EPM, there was increase in entries numbers and time spent in open arm. Decrease in immobility duration observed at low dose while high dose increased immobility duration in FST. Hence outcomes of current study indicate that $S$. cumini have anxiolytic and anti-depressant effect.

Keywords: Antidepressant, Anxiolytic, Syzygium cumini.

\section{INTRODUCTION}

Disorders like anxiety and depression are the most common mental illness in health problems. According to $\mathrm{WHO}$, around 450 million people with $12.3 \%$ of disease burden globally live with psychological or mental disorders and only a small fraction of these people receive the basic treatment. It is expected that this burden will rise till $15 \%$ by 2020 [1]. It has been reported by Anxiety and Depression Association of America (ADAA), 7 out of 10 U.S adults declare that they experience anxiety or stress at average level on daily basis and it's a common part of their life [2].
Currently approximate 340 million people are living with depression worldwide and affecting $21 \%$ of world's population [3]. WHO also indicates that unipolar depression will be the $2^{\text {nd }}$ most leading reason of illness induced disability at the end of 2020 [4].

Anxiety and depression can be treated using various therapies. Benzodiazepines are the drug of choice for reduction of anxiety while monoamine oxidase inhibitors (MOIs) and amine reuptake are largely used in the treatment of depression. However, clinically antidepressants are more profound and replace the benzodiazepines due to their role in the treatment of 
depression and anxiety [5]. According to previous literature, around two-third of the anxiety and depression patients responded to the available treatment [6]. However there is still need for improvement since, due to complex mechanism of depression, many antidepressants have reduced response and produces severe adverse effects like constipation, dry mouth and sexual dysfunction [7]. Hence there is need of more effective and well tolerated treatment.

Literature suggested that alternative form of medicine for the treatment of psychological ailments has played a major role and the most persistent form of such alternative treatment is herbal treatment. Thus researchers are involved in evaluating effective new molecules of plant origin in different animal models [810]. More over in the last 2 centuries, scientific approach for psychoactive plants has been improved particularly after the isolation of psychotropic components.

S. cumini belongs to family Myrtaceae with high flavonoids representing the major fraction of phenolic compounds while essential oil of this plant possessed limonene, dipentene and sesquiterpenes of different types as major components [11]. There are several traditional uses of $S$. cumini such as asthma, ulcers, bronchitis, dysentery, biliousness; diabetes and management of its complications [12]. Experimental studies have shown that $S$. cumini leaves extract possess anti-nociceptive activity, anti-inflammatory activity, antioxidant effect, antimicrobial potential, antidiabetic and antihyperlipidemic potential [11, 13].

Literature survey reveals that there are no reports on neurological and behavioral activity of methanolic extract of $S$. cumini leaves was reported. Hence current research was planned to examine the neurobehavioral potential such as anxiolytic and antidepressant activity of $S$. cumini methanolic leaves extract (SCME) at three different doses in the experimental model of mice.

\section{MATERIALS AND METHODS}

\section{Experimental Animals}

Swiss albino mice were used to conduct this study with average weight of $25 \pm 5 \mathrm{~g}$. Animals were housed in suitable plastic cages under precondition temperature of $25 \pm 2{ }^{\circ} \mathrm{C}$ and were provided easy access to standard diet. The use and care of these animals in our study was in accordance to the guideline presented by National Institute of Health (NIH) [14]. The study was approved by Board of advance studies and researches (BASR) from University of Karachi with reference no BASR/No./02897/Phar

\section{Methanolic extract}

S. cumini leaves were collected freshly and proceed to department of botany, University of Karachi for identification with G.H. No. 94236. The leaves were dried for two weeks, after drying; leaves were transformed into powder and macerated with methanol for 14 days. Filtration of mixture was performed which further proceed to concentrate the filtrate using rotary evaporator at reduced pressure [11].

\section{Drug treatment}

Animals were distributed in to five groups each group having 10 mice. One group received vehicle and was considered as control group and two groups received SCME in the doses of $150 \mathrm{mg} / \mathrm{kg}$ and $500 \mathrm{mg} / \mathrm{kg}$. The remaining two groups received imipramine and diazepam $25 \mathrm{mg} / \mathrm{kg}$ and $3 \mathrm{mg} / \mathrm{kg}$ respectively. Vehicle, SCME and standard drugs were given via oral route for 15 days.

\section{Open Field test}

Anxiety and locomotor activity of animal can be assessed using open field test [15]. Individually each mouse was placed in the center of open field. Time for exploration given for each mouse was 5 minutes and ethanol was used to for floor cleaning after each process. Variables estimated were (1) Number of rearing i.e. How many times mouse stood in the air or against the wall with the forelegs, (2) Rearing duration i.e. time duration of mouse in standing situation, (3) Center entries count i.e. when mouse moved center square, (4) Total distance traveled i.e. total number of squares moved by animal multiplied with size of each square. All tests were recorded using Yashica Digital Zoom Camera by placing it above the open field. Oral route was used for daily administration of SCME; vehicle and diazepam for 15 days. Open field test (OFT) was repeated on $8^{\text {th }}$ and $15^{\text {th }}$ day of the study, after 1 hour of giving drugs.

\section{Elevated Plus Maze}

Anxiety in animals can be measured by EPM [16]. Each mouse was placed in the EPM center. Five minutes were given to each mouse for exploration and then placed in their cages. Number of entries and 
time spent in open and close arms were measured in this test. All tests were recorded by Yashica Digital Zoom Camera from the top view site of the EPM. Oral route was used for daily administration of SCME, vehicle and diazepam for 15 days. This test was done on $8^{\text {th }}$ and $15^{\text {th }}$ day of study, after 1 hour of giving drugs.

\section{Forced Swimming Test}

Depression like activity in rodents can be evaluated using Forced swimming test [17]. Cylinder of apparatus was filled with fresh water up to $20 \mathrm{~cm}$ height. Temperature of water should be maintained around $25^{\circ} \mathrm{C}$. Each mouse was placed in cylinder and activity was observed for $5 \mathrm{~min}$. Replacement of water was done after each animal testing. Variables estimated were (1) Immobility duration, (2) Climbing duration and (3) Swimming duration. ${ }^{28}$ SCME, vehicle and imipramine were administered daily through oral route over a period of 14 days and then animals were exposed to pre-test session after 14 days of treatment. Once again animals were placed in the same condition for $5 \mathrm{~min}$ (test session) after $24 \mathrm{~h}$ of the pre-test session. Test solutions were administered trice a day orally i.e. after the pre-test session, $5 \mathrm{~h}$ and $1 \mathrm{~h}$ before the main test. All tests were recorded by Zoom Camera (Yashica Digital: EZ F10).

\section{Tail Suspension Test (TST)}

A simple, expeditious and reliable method to evaluate the antidepressant potential of drug is tail suspension method. Sherry et al. discussed the method in which immobility duration was induced by tail suspension which is an indication of a depressive state [18]. Each mouse was suspended individually $25 \mathrm{~cm}$ from the bottom by adhesive tape applied on the tip of tail. The immobility duration was recorded during the $6 \mathrm{~min}$ period and considered immobile when animals hung completely and passively motionless. Oral route was used for daily administration of SCME; vehicle and imipramine for 15 days. This test was done on $8^{\text {th }}$ and $15^{\text {th }}$ day of study, after 1 hour of giving drugs. All tests were recorded by Zoom Camera (Yashica Digital: EZ F10).

\section{Statistical Analysis}

Data were demonstrated as mean \pm SD and analysis was performed using statistical one-way ANOVA with post hoc test on SPSS version 23. P-values less than 0.05 for significant and 0.005 were considered for highly significant results.

\section{RESULT}

Table 1 presents the $S$. cumini extract effect on mice behavior in open field test. Rearing numbers and its duration significantly increased on $15^{\text {th }}$ day at 125 and $250 \mathrm{mg} / \mathrm{kg}$ of SC, while highly significant increased at $500 \mathrm{mg} / \mathrm{kg}$ on $15^{\text {th }}$ day compared to standard. Duration of rearing was also increased significantly on $8^{\text {th }}$ day and highly significant at $500 \mathrm{mg} / \mathrm{kg}$ in comparison with control. Significant increase was observed in distance travelled and no. of center entries on $8^{\text {th }}$ day while highly significant increase in center entries on $15^{\text {th }}$ day at $500 \mathrm{mg} / \mathrm{kg}$ dose.

Table 1. Effect of S. cumini extract on behavior of mice in Open Field Test.

\begin{tabular}{|c|c|c|c|c|c|}
\hline \multirow[b]{2}{*}{ Groups } & \multirow[b]{2}{*}{ Days } & \multicolumn{4}{|c|}{ Variables } \\
\hline & & No. of rearing & $\begin{array}{l}\text { Rearing } \\
\text { Duration }\end{array}$ & $\begin{array}{c}\text { Distance travelled } \\
(\mathrm{cm})\end{array}$ & $\begin{array}{l}\text { No. of center } \\
\text { entries }\end{array}$ \\
\hline \multirow{2}{*}{ Control } & 8 & $11.8 \pm 1.15$ & $19.5 \pm 1.91$ & $2178.0 \pm 40.36$ & $6.8 \pm 0.58$ \\
\hline & 15 & $11.4 \pm 0.92$ & $18.8 \pm 1.53$ & $2157.0 \pm 58.94$ & $7.6 \pm 0.51$ \\
\hline \multirow{2}{*}{ SC 125} & 8 & $14.4 \pm 1.50$ & $21.2 \pm 2.13$ & $2304.0 \pm 97.25$ & $8.6 \pm 0.23$ \\
\hline & 15 & $18.4 \pm 0.81^{*}$ & $28.5 \pm 1.34^{*}$ & $2313.8 \pm 98.42$ & $9.6 \pm 0.51$ \\
\hline \multirow{2}{*}{ SC 250} & 8 & $15.2 \pm 1.12$ & $24.3 \pm 1.92$ & $2350.2 \pm 47.11$ & $8.9 \pm 0.13$ \\
\hline & 15 & $20.4 \pm 0.91^{*}$ & $30.4 \pm 1.51^{*}$ & $2432.0 \pm 51.91$ & $10.6 \pm 0.65$ \\
\hline \multirow{2}{*}{ SC 500} & 8 & $17.1 \pm 1.35^{\star}$ & $26.8 \pm 0.86^{*}$ & $2655.0 \pm 58.28^{*}$ & $9.4 \pm 0.51^{*}$ \\
\hline & 15 & $22.6 \pm 0.74^{* *}$ & $35.2 \pm 0.66^{\star *}$ & $2640.0 \pm 39.96^{*}$ & $12.5 \pm 0.58^{* *}$ \\
\hline \multirow{2}{*}{ Diazepam } & 8 & $20.4 \pm 1.28^{\star \star}$ & $31.2 \pm 4.55^{\star}$ & $2662.0 \pm 162.23^{*}$ & $10.1 \pm 0.92^{*}$ \\
\hline & 15 & $22.3 \pm 1.56^{\star *}$ & $33.1 \pm 2.58^{* *}$ & $2666.4 \pm 89.25^{*}$ & $14.9 \pm 1.07^{* *}$ \\
\hline
\end{tabular}

$\mathrm{n}=10$, Mean \pm S.D

*Level of significance: $\leq 0.05$, when compared with control

**High level of significance: $\leq 0.005$, when compared with control 
Table 2 presents the effect of SCME on mice behavior in EPM. Significant increase in no. of entries in open arm at $250 \mathrm{mg} / \mathrm{kg}$ while highly significant increases in no. of entries in open arm at $500 \mathrm{mg} / \mathrm{kg}$ were observed on both days. Significant increase in open arm time spent and decrease in close arm observed at $125 \mathrm{mg} / \mathrm{kg}$ and $250 \mathrm{mg} / \mathrm{kg}$ on $8^{\text {th }}$ and $15^{\text {th }}$ days. However, highly significant increase in time spent in open arm was observed at $500 \mathrm{mg} / \mathrm{kg}$ on $8^{\text {th }}$ and $15^{\text {th }}$ days which are comparable to the standard group.
Figure 1 shows the SCME effect in percent comparison from control in mice behavior in FST. Significant decrease and increase in duration of immobility and swimming was observed at $125 \mathrm{mg} / \mathrm{kg}$ respectively while significant decrease in climbing duration was observed at $500 \mathrm{mg} / \mathrm{kg}$ in comparison with control. Figure 2 presents the effect of SCME on mice behavior in tail suspension test. SCME at doses of 250 and $500 \mathrm{mg} / \mathrm{kg}$ showed significant reduction in immobility time on both $8^{\text {th }}$ and $15^{\text {th }}$ days.

Table 2. Effect of S. cumini extract on behavior of mice in Elevated Plus Maze.

\begin{tabular}{|c|c|c|c|c|c|}
\hline \multirow[b]{2}{*}{ Groups } & \multirow[b]{2}{*}{ Days } & \multicolumn{4}{|c|}{ Variables } \\
\hline & & $\begin{array}{l}\text { No. of entries in } \\
\text { open arm }\end{array}$ & $\begin{array}{l}\text { No. of entries in } \\
\text { close arm }\end{array}$ & $\begin{array}{l}\text { Time spend in } \\
\text { open arm (Sec) }\end{array}$ & $\begin{array}{l}\text { Time spend in } \\
\text { close arm (Sec) }\end{array}$ \\
\hline \multirow{2}{*}{ Control } & 8 & $8.2 \pm 0.58$ & $6.6 \pm 0.92$ & $131.2 \pm 3.59$ & $168.8 \pm 3.59$ \\
\hline & 15 & $8.4 \pm 0.51$ & $5.6 \pm 0.51$ & $130.0 \pm 4.32$ & $170.0 \pm 4.32$ \\
\hline \multirow{2}{*}{ SC 125} & 8 & $9.8 \pm 0.37$ & $6.8 \pm 0.44$ & $159.0 \pm 4.78^{*}$ & $141.0 \pm 4.78^{*}$ \\
\hline & 15 & $9.8 \pm 0.66$ & $5.9 \pm 0.58$ & $155.2 \pm 3.58^{*}$ & $144.8 \pm 3.58^{*}$ \\
\hline \multirow{2}{*}{ SC 250} & 8 & $10.9 \pm 0.87^{*}$ & $6.1 \pm 0.33$ & $168.8 \pm 4.32^{*}$ & $131.2 \pm 6.71^{*}$ \\
\hline & 15 & $11.8 \pm 0.67^{*}$ & $5.4 \pm 0.43$ & $166.5 \pm 3.88^{*}$ & $133.5 \pm 5.11^{*}$ \\
\hline \multirow{2}{*}{ SC 500} & 8 & $13.4 \pm 0.67^{* *}$ & $5.9 \pm 0.58$ & $183.8 \pm 5.12^{\star \star}$ & $116.2 \pm 5.12^{* *}$ \\
\hline & 15 & $13.8 \pm 0.58^{\star *}$ & $3.9 \pm 0.31^{*}$ & $189.2 \pm 4.88^{\star *}$ & $110.8 \pm 4.88^{* *}$ \\
\hline \multirow{2}{*}{ Diazepam } & 8 & $15.6 \pm 0.67^{\star \star}$ & $3.4 \pm 0.44^{*}$ & $190.6 \pm 3.41^{\star *}$ & $109.4 \pm 3.41^{* *}$ \\
\hline & 15 & $13.2 \pm 0.81^{*}$ & $4.2 \pm 0.58^{*}$ & $181.1 \pm 8.35^{\star *}$ & $118.9 \pm 8.35^{\star *}$ \\
\hline
\end{tabular}

$\mathrm{n}=10$, Mean \pm S.D

*Level of significance: $\leq 0.05$, when compared with control

${ }^{*}$ High level of significance: $\leq 0.005$, when compared with control

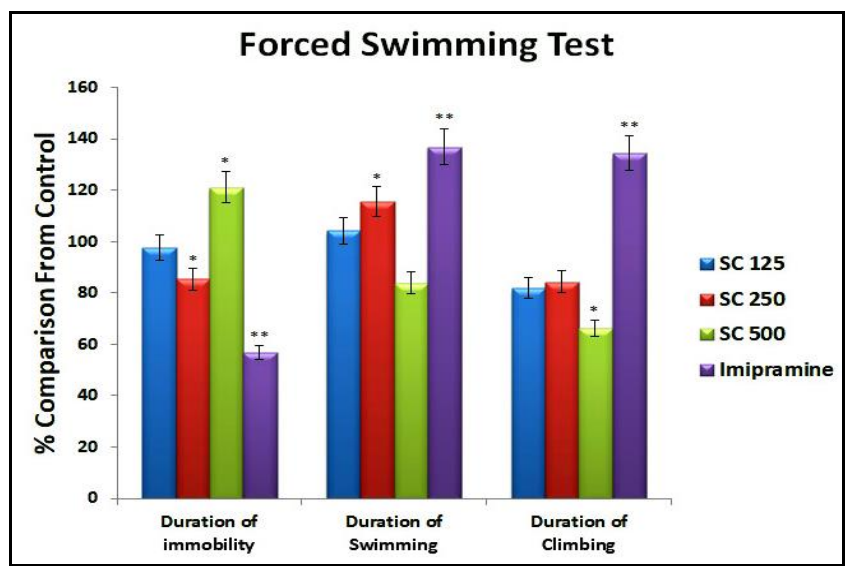

Figure 1. Effect of $S$. cumini extract in percent comparison from control in force swimming test. Data is represented as average values \pm SEM, where $\mathrm{n}=10 ;{ }^{*} p \leq 0.05$ significant as compared to control, ${ }^{*} p$ $\leq 0.005$ highly significant as compared to control.

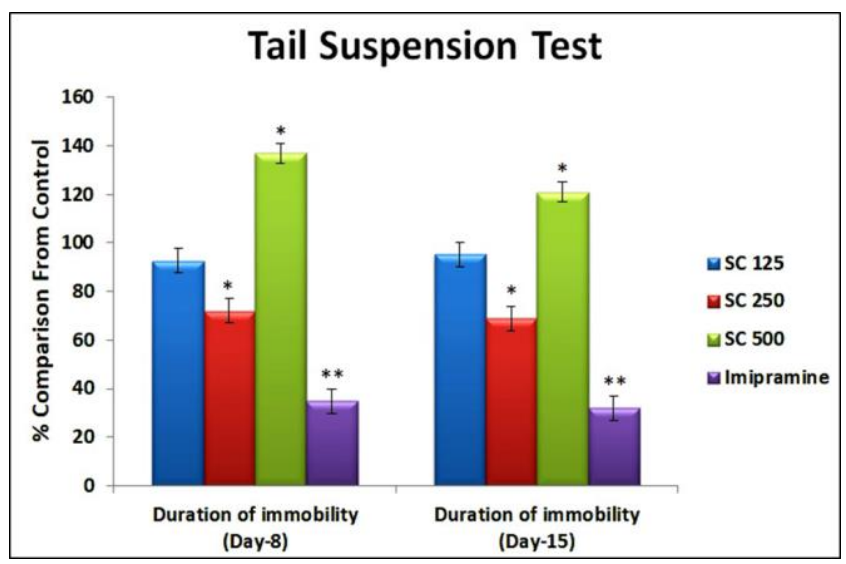

Figure 2. Effect of $S$. cumini extract in percent comparison from control in tail suspension test. Data is represented as average values \pm SEM, where $\mathrm{n}=10 ;{ }^{*} p \leq 0.05$ significant as compared to control, * $p$ $\leq 0.005$ highly significant as compared to control. 


\section{DISCUSSION}

The current study was conducted to assess the anxiolytic and antidepressant effect of SCME at different doses (125, 250 and $500 \mathrm{mg} / \mathrm{kg}$ ) using EPM and OFT for anxiolytic activity while FST and TST for antidepressant activity.

Highly significant increase was observed at dose of $500 \mathrm{mg} / \mathrm{kg}$ in rearing numbers and its duration; these results were almost similar to the standard treatment group which suggests improved locomotor action [19]. While increase in distance travelled at $500 \mathrm{mg} / \mathrm{kg}$ on $15^{\text {th }}$ day shows improved motor activity and central nervous system stimulation [20]. These results reflect low anxiety potential and high exploratory behavior of S. cumini. In OFT data of percent comparison from control, distance travelled at $500 \mathrm{mg} / \mathrm{kg}$ on both days which was similar to the standard treatment while rearing and duration of rearing were greater than the standard group on $15^{\text {th }}$ day which shows the highest locomotor activity at high dose of SCME used in this study.

In EPM 125 and $250 \mathrm{mg} / \mathrm{kg}$ showed elevation in open arm time spend however highly significant increase in entries of open arm and time spend at $500 \mathrm{mg} / \mathrm{kg}$ on both days in comparison with standard diazepam groups. In EPM data of percent comparison from control, entries in number and time spend in open arm at $500 \mathrm{mg} / \mathrm{kg}$ were more than standard group on $15^{\text {th }}$ day while entries in number and time spend in close arm at $500 \mathrm{mg} / \mathrm{kg}$ were reduced on $15^{\text {th }}$ day.

All these behavioral actions of SCME can be perceived with respect to CNS stimulant and anxiolytic effects. Hence such behavior is the actual interpretation of increased locomotory response by treated animals [21]. Due to the similar type of phenotype, it is very difficult to distinguish the underlying mechanism of CNS stimulant and anxiolytic drugs. It also has been reported that various plant species possessed anxiolytic activity due to the presence of flavonoids, used in folk medicine [22]. Therefore, anxiolytic effects of SCME could be linked with their flavonoids content which modulates neurological processes involved in anxiety particularly Gamma-Amino Butyric Acid (GABA) receptors [23].

Depression can be distinguished by neuroendocrine, psychosomatic and somatic symptoms. Most commonly method used for evaluation of depression in animals are FST and TST. Thus some phases of human depression resemble with the immobility behavior of animals during these tests [24]. Immobility is one of the variables in FST and TST that indicate hopeless and depressive behavior of the animal. Reduction in immobility period shows anti-depressant potential [25]. When compared with control, 125 and $250 \mathrm{mg} / \mathrm{kg}$ have shown reduction in duration of immobility however, these doses increase the duration of swimming which in turn counter balance the immobility duration. This behavior was also observed in case of imipramine group and it has also been reported that imipramine effects are associated with decrease in duration of immobility which is further compensated by improved swimming duration [26].

Figure (3 and 4) showed reduction in immobility duration in a dose dependent manner at 125 and 250 $\mathrm{mg} / \mathrm{kg}$ however duration of immobility was increased at a dose of $500 \mathrm{mg} / \mathrm{kg}$ which indicates its depressive effect and it could be due to the presence saponins in high levels in the SCME [27]. Role of saponins was reported in various studies as CNS depressant due to its agonistic response on GABA-A receptor complex [28, 29]. Hence therapeutic levels of drug concentration can be achieved by the adjustment of dose. Although this study design does not explain about the active moiety through which pharmacological effects are possible but on other side, it let us imitate experimentally a condition analogous to the addition of the $S$. cumini in the human diet.

Composition of flavonoids in SCME leaf is approximately $451.50 \pm 9.85 \mathrm{mg} / \mathrm{g}$, while 23-68.2 $\mathrm{mg} /$ day is the average intake of flavonoids in adult $[12,30]$. Therefore, in this study both doses of $S$. cumini leaf extract were used to accomplish the daily needs of flavonoids. Indeed, flavonoids are, in part, synergistic concerning its biological actions.

\section{CONCLUSION}

Our results make evident that the leaves of SCME possess good anxiolytic on all three doses while antidepressant properties on two doses. As per obtained results of this study allows us to propose this plant to choice for isolating new active moieties with potential antidepressant and anxiolytic activity. Although further clinical investigations are necessary but these results are promising since $S$. cumini might be considered as an alternative for the treatment of 
such mental illness to other medications currently used.

\section{REFERENCES}

1. Nguyen T, Tran T, Green S, Hsueh A, Tran T, Tran $\mathrm{H}$, et al. Delays to diagnosis among people with severe mental illness in rural Vietnam, a population-based cross-sectional survey. BMC Psychiarty. 2019; 19(1):385.

Doi: 10.1186/s12888-019-2367-1.

2. Melson-Silimon A, Harris AM, Shoenfelt EL, Miller JD, Carter NT. Personality testing and the Americans with Disabilities Act: Cause for concern as normal and abnormal personality models are integrated. Ind Org Psychol. 2019; 12(2):119-32. Doi: 10.1017/iop.2018.156.

3. Organization WH. Depression and other common mental disorders: global health estimates. World Health Organization; 2017.

4. Corlier J, Burnette E, Wilson AC, Lou JJ, Landeros A, Minzenberg MJ, et al. Effect of Repetitive Transcranial Magnetic Stimulation (rTMS) Treatment of Major Depressive Disorder (MDD) on Cognitive Control. J Affect Dis. 2020;265:272-7. Doi: 10.1016/j.jad.2020.01.068.

5. Andreescu C, Lee S. Anxiety Disorders in the Elderly. Anxiety Disorders: Springer; 2020. p. 56176.

Doi: 10.1007/978-981-32-9705-0_20.

6. Perkins-Porras L, Riaz M, Okekunle A, Zhelezna S, Chakravorty I, Ussher MJ. Feasibility study to assess the effect of a brief mindfulness intervention for patients with chronic obstructive pulmonary disease: a randomized controlled trial. Chron Resp Dis. 2018; 15(4):400-10.

Doi: $10.1177 / 1479972318766140$.

7. Ferguson K, Wolfgram N. Antidepressants in Pain Management. Deer's Treatment of Pain: Springer; 2019. p. 191-8.

Doi: 10.1007/978-3-030-12281-2_23.

8. Mumtaz N, Asghar MA, Naqvi SBS, Asghar MA, Raza ML, Rehman AA et al. Time kill assay and bactericidal mechanism of action of ethanolic flowers extract of Sphaeranthus indicus. RADs J Pharm Pharm Sci. 2019;7(1):27-33.

9. Shafiq $Y$, Naqvi SBS, Rizwani GH, Abbas $T$, Sharif $\mathrm{H}$, Ali $\mathrm{H}$, et al. Assessment of killing kinetics assay and bactericidal mechanism of crude methanolic bark extract of Casuarina equisetifolia. Pak J Pharm Sci. 2018;31(5):2143-8.

10. Delkhosh-Kasmaie F, Farshid AA, Tamaddonfard $E$, Imani MJ. The effects of safranal, a constitute of saffron, and metformin on spatial learning and memory impairments in type- 1 diabetic rats: behavioral and hippocampal histopathological and biochemical evaluations. Biomed Pharmacother 2018;107:203-11.

Doi: 10.1016/j.biopha.2018.07.165.

11. Rehman AA, Riaz A, Asghar MA, Raza ML, Ahmed $\mathrm{S}$, Khan $\mathrm{K}$, et al. In vivo assessment of anticoagulant and antiplatelet effects of Syzygium cumini leaves extract in rabbits. BMC Complement Altern Med 2019; 19(1):236.

Doi: 10.1186/s12906-019-2661-y.

12. Pandey MM, Rawat A. Pharmacognosy and Pharmacopoeial Standards for Syzygium cumini. The Genus Syzygium: CRC Press; 2017. p. 11932.

13. George V, Pushpangadan P. Biological Activities of Syzygium cumini and Allied Species. The Genus Syzygium: CRC Press; 2017. p. 133-62.

14. Narver HL, Hoogstraten-Miller S, Linkenhoker J, Weichbrod RH. Tributes for animals and the dedicated people entrusted with their care: a practical how-to guide. Lab Animal. 2017;46(10):369-72.

Doi: 10.1038/laban.1346

15. Kraeuter A-K, Guest PC, Sarnyai Z. The open field test for measuring locomotor activity and anxietylike behavior. Pre-Clinical Models: Springer; 2019. p. 99-103.

Doi: 10.1007/978-1-4939-8994-2_9.

16. Kraeuter A-K, Guest PC, Sarnyai Z. The elevated plus maze test for measuring anxiety-like behavior in rodents. Pre-Clinical Models: Springer; 2019. p. 69-74.

Doi: 10.1007/978-1-4939-8994-2_4.

17. Ostadhadi S, Norouzi-Javidan A, Chamanara M, Akbarian $R$, Imran-Khan $M$, Ghasemi $M$, et al. Involvement of NMDA receptors in the antidepressant-like effect of tramadol in the mouse forced swimming test. CNS drugs. 2017;134:13641.

Doi: 10.1016/j.brainresbull.2017.07.016.

18. Said SA, Isedowo R, Guerin C, Nar NN, Lillie L, Bukovac S, et al. Effects of long-term dietary administration of estrogen receptor-beta agonist diarylpropionitrile on ovariectomized female ICR (CD-1) mice. GeroSci. 2018;40(4):393-403.

Doi: 10.1007/s11357-018-0038-7.

19. Chaves EMC, Honório-Júnior JER, Sousa CNS, Monteiro VS, Nonato DTT, Dantas LP, et al. The anxiolytic-like effect of 6-styryl-2-pyrone in mice involves GABAergic mechanism of action. Metabol Brain Dis. 2018;33(1):139-49. 
Doi: 10.1007/s11011-017-0139-5.

20. Goganau I, Sandner B, Weidner N, Fouad K, Blesch AJ. Depolarization and electrical stimulation enhance in vitro and in vivo sensory axon growth after spinal cord injury. J Neural Eng. 2018;300:247-58.

Doi: 10.1016/j.expneurol.2017.11.011.

21. Koolhaas J, Van Reenen CJ. Animal behavior and well-being symposium: Interaction between coping style/personality, stress, and welfare: Relevance for domestic farm animals. J Animal Sci 2016;94(6):2284-96.

Doi: 10.2527/jas.2015-0125.

22. Bharate SS, Mignani S, Vishwakarma RA. Why are the majority of active compounds in the CNS domain natural products? A critical analysis. J Med Chem. 2018;61(23):10345-74.

Doi: 10.1021/acs.jmedchem.7b01922.

23. Sheth C, Prescot AP, Legarreta M, Renshaw PF, McGlade E, Yurgelun-Todd DJ. Reduced gammaamino butyric acid (GABA) and glutamine in the anterior cingulate cortex (ACC) of veterans exposed to trauma. J Affec Dis 2019;248:166-74. Doi: 10.1016/j.jad.2019.01.037.

24. Melleu F, Pinheiro M, Lino-de-Oliveira C, MarinoNeto JJ. Defensive behaviors and prosencephalic neurogenesis in pigeons (Columba livia) are affected by environmental enrichment in adulthood. Avain Res. 2016;221(4):2287-301.

Doi: 10.1007/s00429-015-1043-6.

25. Umukoro S, Adebesin A, Agu G, Omorogbe O, Asehinde SB. Antidepressant-like activity of methyl jasmonate involves modulation of monoaminergic pathways in mice. Adv Med Sci. 2018;63(1):36-42. Doi: 10.1016/j.advms.2017.07.005.
26. Paolo S, Galistu AJ. Imipramine administered before the first of two forced swim sessions results in reduced immobility in the second session $24 \mathrm{~h}$ later. Behave Brain Res. 2019;373:112088.

Doi: 10.1016/j.bbr.2019.112088.

27. Du H, Wang K, Su L, Zhao H, Gao S, Lin Q, et al. Metabonomic identification of the effects of the Zhimu-Baihe saponins on a chronic unpredictable mild stress-induced rat model of depression. J Pharm Biomed Anal. 2016;128:469-79.

Doi: 10.1016/j.jpba.2016.06.019.

28. Sultana T, Mannan MA, Ahmed TJ. Evaluation of central nervous system (CNS) depressant activity of methanolic extract of Commelina diffusa Burm. in mice. Clinic Phytosci. 2018;4(1):5.

Doi: 10.1186/s40816-018-0063-1.

29. Mustafa G, Ansari S, Bhat Z, Abdulkareim A. Antianxiety Activities Associated with Herbal Drugs: A Review. Plant and Human Health, Volume 3: Springer; Plant Hum Health. 2019. p. 87-100.

Doi: 10.1007/978-3-030-04408-4_5.

30. Ziauddeen N, Rosi A, Del Rio D, Amoutzopoulos $B$, Nicholson S, Page $P$, et al. Dietary intake of (poly) phenols in children and adults: Crosssectional analysis of UK National Diet and Nutrition Survey Rolling Programme (2008-2014). Eur J Nutr. 2019;58(8):3183-98.

Doi: $10.1007 / \mathrm{s} 00394-018-1862-3$.

This is an Open Access article distributed under the terms of the Creative Commons Attribution License (http://creativecommons.org/licenses/by/4.0), which permits unrestricted use, distribution, and reproduction in any medium, provided the original work is properly cited. 